\title{
House Prices, per Capita Income and Real Estate Planning Investment-An Empirical Study Based on Anhui Province
}

\author{
Yingying Zhang \\ School of Finance, Anhui University of Finance and Economics, Bengbu, China \\ Email: ZhangYing-ying@163.com
}

How to cite this paper: Zhang, Y. Y. (2020). House Prices, per Capita Income and Real Estate Planning Investment-An Empirical Study Based on Anhui Province. Open Journal of Social Sciences, 8, 37-43. https://doi.org/10.4236/jss.2020.86004

Received: May 6, 2020

Accepted: May 30, 2020

Published: June 2, 2020

Copyright $\odot 2020$ by author(s) and Scientific Research Publishing Inc. This work is licensed under the Creative Commons Attribution International License (CC BY 4.0).

http://creativecommons.org/licenses/by/4.0/

\begin{abstract}
In order to explore the relationship between housing prices, per capita disposable income and real estate planning investment, this article uses the data of average sales price of Anhui Province from 2000 to 2018, per capita disposable income and real estate planning investment as samples to establish multiple linear regression. The model found a significant positive correlation between house prices and income. By using EVIEWS9.0 analysis software, three quantitative relationship between those who came to the conclusion functional relationship is: $\ln \widehat{Y}_{t}=5.1649+0.0803 \widehat{X_{1 t}}+0.4266 \widehat{X_{2 t}}$.
\end{abstract}

\section{Keywords}

House Prices, Per Capita Disposable Income, Multiple Linear Regression

\section{Introduction}

With the development of the economy, housing prices in Chinese cities have experienced significant growth. By 2004 onwards to Beijing, Shanghai and other urban centers as the representative of more rapid rises in house prices, the annual average increase is far more than $20 \%$. An investment tycoon seized market opportunities and turned to investing in real estate, the real estate industry soared unprecedentedly. At the same time, the increase in the per capita disposable income of urban residents far lags behind the growth rate of housing prices and real estate investment. The trend of rising house prices is not only in the central cities, and the growth rate of house prices in many second-tier and third-tier cities has also started to increase. The Chinese people have paid attention to the concept of home since ancient times. The rapid increase in house 
prices has also attracted the attention of the government and many scholars.

In the research on the factors affecting house prices, Kuang (2010) analyzed panel data and found that interest rate changes and the speed of population growth have a more significant impact on housing price fluctuations. Gao et al. (2013) found that the excessive urban-rural income gap led to an increase in urban housing rents, and the per capita disposable income of residents was the most significant among all influencing factors. Li (2014) found that changes in housing demand, changes in the quality of housing supply, and differences in the housing environment will all lead to changes in housing prices. In addition to studying the relationship between housing supply and demand and the factors affecting housing prices, Wang et al. (2015) found that economic growth and population growth will increase housing prices based on panel data. Yuan et al. (2016) summarized the relevant literature and found that the main impact on housing price changes is the price of land and government behavior. Regarding the research on the influencing factors of housing prices from a spatial perspective, Liu and Xu (2019) focused on the analysis of the effects of the four indicators of economic development, land supply, population demand and development investment on housing price changes.

In the quantitative analysis of housing price trends, Qiu and Yu (2011) established a BP neural network model based on principal component analysis to improve the accuracy of house price prediction. Zhang (2014) established a multiple regression model to predict housing prices in Suzhou. Gan et al. (2016) constructed a structural equation model to study the dynamic relationship between housing prices and land price changes in Beijing. Zhang and Li (2016) used house prices and land prices to predict house prices, proving that house price expectations have a greater impact on land prices. Li and Guo (2020) used GM $(1,1)$ model and BP neural network model to analyze Nanjing short-term data. Zhu (2020) impact of disposable income on housing prices in Chongqing City is using the traditional linear regression method.

In summary, most scholars will refer to the supply and demand relationship of the housing market when studying the factors influencing housing prices. Residents' disposable income has a greater impact on housing demand. At the same time, scholars did not mention the effect of planned investment on house price changes, so this article will choose two factors: average disposable income of residents and planned investment of housing to establish a multiple linear regression equation and quantitative analysis.

\section{Empirical Research}

\subsection{Theoretical Models and Data Sources}

Housing is a special consumer product, not only has practical value but also has investment value. From the consumer's point of view, no matter what type of product you get, you have to spend money to buy the product. The sales of the product depend in part on the purchasing power of the consumer. For consum- 
ers who have a demand for housing or housing, the higher the personal disposable income, the greater the demand and desire for housing purchases, and the price of goods depends on market demand rise. From an investor's perspective, the investor sees an increase in demand for housing in the market, and his desire for real estate investment will become more intense, which will also lead to rising housing prices. It can be seen that consumers "disposable income and investors" planned investment affect the selling price of houses by affecting the demand side of the real estate market.

Among many data analysis methods, regression analysis has been favored by some scholars as a more widely used quantitative analysis method. It analyzes the statistical relationship between things while focusing on considering the law of quantitative change between variables, and finally through regression. The form of the equation directly describes this relationship. The general multiple linear regression equation format is:

$$
Y_{t}=\beta_{0}+\beta_{1} X_{1}+\beta_{2} X_{2}+\cdots+\beta_{n} X_{n}
$$

After the linear regression equation is established on the basis of collecting sample data, statistical fitting should be performed on him. The commonly used statistical fitting criterion is the ordinary least squares method (OLSE method). For multiple linear regression equations, there are:

$$
Q\left(\beta_{0}, \beta_{1}, \cdots, \beta_{n}\right)=\sum_{t=1}^{n}\left(y_{t}-\beta_{0}-\beta_{1} x_{1 t}-\cdots-\beta_{p} x_{t p}\right)^{2}
$$

Least squares estimation is to find the estimated value of each parameter and make the parameter estimated value reach the minimum, namely:

$$
\begin{aligned}
Q\left(\beta_{0}, \beta_{1}, \cdots, \beta_{n}\right) & =\sum_{t=1}^{n}\left(y_{t}-\beta_{0}-\beta_{1} x_{1 t}-\cdots-\beta_{p} x_{t p}\right)^{2} \\
& =\min _{\beta_{0}, \beta_{1}, \cdots, \beta_{n}} \sum_{t=1}^{n}\left(y_{t}-\beta_{0}-\beta_{1} x_{1 t}-\cdots-\beta_{p} x_{t p}\right)^{2}
\end{aligned}
$$

All data in this article are derived from the official data released by the National Bureau of Statistics, showing in Table 1. According to the data, it can be seen that the selling price per square meter of houses in Anhui Province is increasing year by year.

\subsection{Building the Model}

In different periods, house prices will be different, and many factors can affect the change in house prices. This article mainly studies the impact of residents "personal disposable income and investors" investment factors in real estate plans on house prices. By setting house prices as the dependent variable and per capita disposable income as the independent variable showing in Figure 1, it can be found that there is a more obvious linear fitting relationship between the house sales price $(Y)$ and the per capita disposable income $\left(X_{1}\right)$ and the real estate plan investment $\left(X_{2}\right)$. Showing in Table 2, the correlation coefficient between the minimum index 0.9657 , max 0.9929 , indicating a correlation between the strength of the indicators. 
Table 1. Average house price, per capita income and planned investment in Anhui Province.

\begin{tabular}{cccc}
\hline time & $\begin{array}{c}\text { Average selling price of houses } \\
\text { (yuan/square meter) }\end{array}$ & $\begin{array}{c}\text { Per capita disposable } \\
\text { income (yuan/person) }\end{array}$ & $\begin{array}{c}\text { Real estate planned investment } \\
(100 \text { million yuan) }\end{array}$ \\
\hline 2004 & 1782.14 & 7511.43 & 1448.54 \\
2005 & 2220.20 & 8470.68 & 1930.11 \\
2006 & 2321.89 & 9771.05 & 2505.19 \\
2007 & 2664.37 & $11,473.58$ & 3213.53 \\
2008 & 2949.00 & $12,990.35$ & 4807.41 \\
2009 & 3420.00 & $14,085.74$ & 6454.32 \\
2010 & 4205.00 & $15,788.17$ & 8956.29 \\
2011 & 4776.10 & $18,606.13$ & $11,695.45$ \\
2012 & 4824.95 & $21,024.21$ & $15,455.24$ \\
2013 & 5080.00 & $23,114.22$ & $19,840.91$ \\
2014 & 5394.00 & $24,838.52$ & $22,643.46$ \\
2015 & 5457.00 & $26,936.00$ & $25,105.30$ \\
2016 & 5924.00 & $29,156.00$ & $28,041.43$ \\
2017 & 6375.00 & $31,640.32$ & $33,463.64$ \\
2018 & 7049.86 & $34,393.00$ & $36,071.76$ \\
\hline
\end{tabular}

Table 2. Variable correlation.

\begin{tabular}{cccc}
\hline & House price & Per capita disposable income & Real estate investment \\
\hline House price & 1.0000 & 0.9852 & 0.9929 \\
Per capita disposable income & 0.9852 & 1.0000 & 0.9657 \\
Real estate investment & 0.9657 & 0.9929 & 1.0000 \\
\hline
\end{tabular}

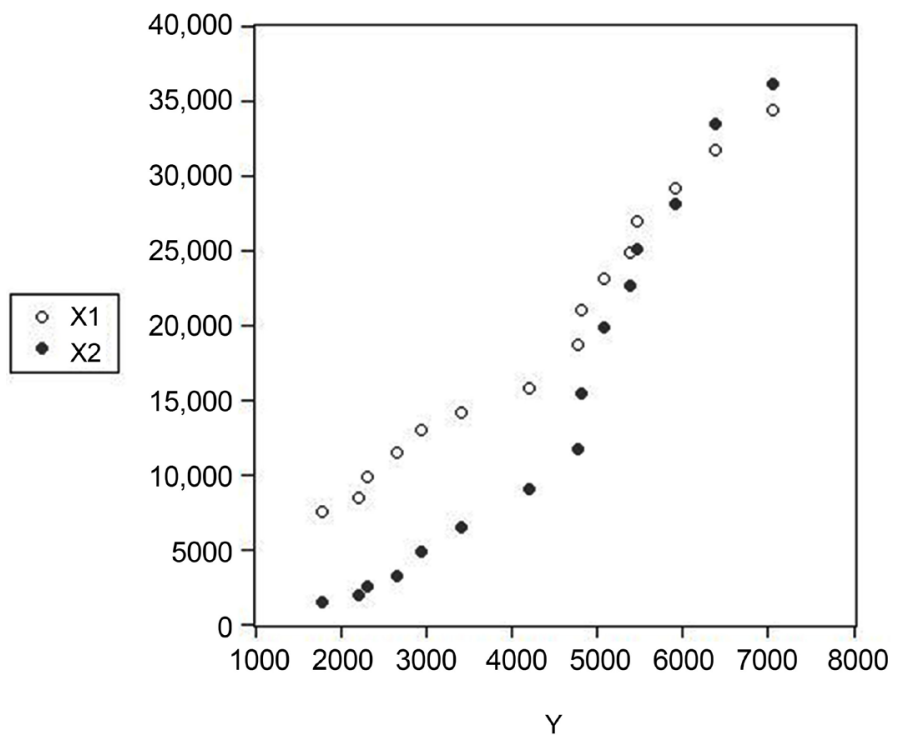

Figure 1. Scatter plot of house price, per capita income and planned investment in Anhui Province. 
Based on the above analysis and economic theory, a multivariate linear regression equation for factors affecting housing prices in Anhui Province is initially established:

$$
Y=\alpha+\beta X_{1 t}+\gamma X_{2 t}+\mu_{t}
$$

Among them $\alpha, \beta, \gamma$ are the parameters of the linear regression equation, which $\mu_{t}$ are random disturbance terms.

In order to ensure the authenticity and validity of the data with accuracy, reflecting the relationship between the variables facilitates, on $Y, X$ two variables logarithmic transformation, can be obtained:

$$
\ln Y=\alpha+\beta \ln X_{1 t}+\gamma \ln X_{2 t}+\mu_{t}
$$

\subsection{Empirical Analysis}

Using EVIEWS9.0 software to perform OLS regression on the variables, the following results are obtained:

$$
\begin{aligned}
\ln \widehat{Y_{t}}= & 5.1649+0.0803 \widehat{X_{1 t}}+0.4266 \widehat{X_{2 t}} \\
& (0.0193)(0.8162) \quad(0.0161)
\end{aligned}
$$

Fit coefficients of the linear regression equation is 0.9864 , indicating that $5 \%$ was significantly lower level of disposable income when prices change for better explanation. The coefficients before $X_{1}$ and $X_{2}$ are both positive numbers. It can be understood that with the increase of residents' disposable income and investment in real estate planning, the price of houses will also increase, and there is a positive correlation between variables. In the case of other conditions remain unchanged, the average per capita disposable income increased 1 percent, housing prices will increase an average of 0.0803 percent; Housing plans to invest an average increase of 1 percentage point increase in the average price of houses 0.4266 percentage points.

\subsection{Heteroscedasticity Test}

If the random error term of the linear regression model has heteroscedasticity, it will have a greater impact on the model parameter estimation and testing. Therefore, the heteroscedasticity test needs to be used to ensure the practical application of the model.

Cook distance is widely used in exploring abnormal points. Its mathematical definition is:

$$
D_{i}=\frac{e_{i}^{2}}{(p+i) \hat{\sigma}^{2}} \times \frac{h_{i j}}{\left(1-h_{i i}\right)^{2}}
$$

In the EVIEWS operation, showing in Figure 2, draw the following test results $\operatorname{Prob}\left(n R^{2}\right)=0.8666>0.05$, taking $5 \%$ significance level, the residual heteroskedasticity absent, i.e., indicate the absence of heteroscedasticity multiple linear regression equation after taking pair. 
Heteroskedasticity Test: White

\begin{tabular}{llll}
\hline \hline F-statistic & 0.256652 & Prob. F(5,9) & 0.9258 \\
Obs^R-squared & 1.871865 & Prob. Chi-Square(5) & 0.8666 \\
Scaled explained SS & 0.767919 & Prob. Chi-Square(5) & 0.9790 \\
\hline
\end{tabular}

\begin{tabular}{|c|c|c|c|c|}
\hline $\begin{array}{l}\text { Method: Least Squa } \\
\text { Date: } 04 / 27 / 20 \text { Tim } \\
\text { Sample: } 20042018 \\
\text { Included observation }\end{array}$ & $\begin{array}{l}\mathrm{SID}^{\wedge} 2 \\
0: 28 \\
5\end{array}$ & & & \\
\hline Variable & Coefficient & Std. Error & t-Statistic & Prob. \\
\hline C & 8.712990 & 14.72266 & 0.591808 & 0.5685 \\
\hline LNX1^2 & 0.247829 & 0.465893 & 0.531945 & 0.6076 \\
\hline LNX1*LNX2 & -0.210136 & 0.425350 & -0.494030 & 0.6331 \\
\hline LNX1 & -2.939730 & 5.226248 & -0.562493 & 0.5875 \\
\hline LNX2^2 & 0.044517 & 0.097932 & 0.454571 & 0.6602 \\
\hline LNX2 & 1.247198 & 2.370785 & 0.526069 & 0.6116 \\
\hline R-squared & 0.124791 & Mean depe & lent var & 0.002346 \\
\hline Adjusted R-squared & -0.361436 & S.D. depen & ent var & 0.002750 \\
\hline S.E. of regression & 0.003209 & Akaike info & iterion & -8.356689 \\
\hline Sum squared resid & 9.27E-05 & Schwarz cl & erion & -8.073469 \\
\hline Log likelihood & 68.67516 & Hannan-Qu & in criter. & -8.359706 \\
\hline F-statistic & 0.256652 & Durbin-Wa & on stat & 2.309172 \\
\hline Prob(F-statistic) & 0.925820 & & & \\
\hline
\end{tabular}

Figure 2. White test.

\section{Conclusion}

According to the econometric model created, there is a clear positive correlation between house prices and personal disposable income and planned investment of real estate, and personal disposable income and planned investment of real estate both significantly affect changes in house prices. The functional relationship between the three is $\ln \widehat{Y}_{t}=5.1649+0.0803 \widehat{X_{1 t}}+0.4266 \widehat{X_{2 t}}$. It can be seen that the planned investment in real estate and the change in house prices are relatively close, but the growth rate of personal disposable income is slower than the rise in house prices.

Commodity prices reflect market supply and demand, and house prices reflect housing market supply and demand. The disposable income of residents used in the research is based on the average disposable income of all residents in Anhui Province. It cannot represent some high-income and low-income people. For some low-income people, it may be difficult to meet their consumer needs, but houses are special commodities. The government cannot forcefully interfere in its selling price. In order to alleviate the pressure of urban housing demand, the government can make full use of the role of the real estate market mechanism, reduce or avoid manipulative market manipulation, and protect low-income people while respecting the investment real estate market demand. The housing demand is to achieve a healthy, orderly and long-term development of the real 
estate market. Due to the existence of rigid demand, increasing housing supply cannot suppress house prices. It is necessary to control the capital of the real estate market to avoid investors blindly investing in the real estate market, which may lead to a "bubble economy" and appropriately reduce the role of high housing prices.

\section{Conflicts of Interest}

The author declares no conflicts of interest regarding the publication of this paper.

\section{References}

Gan, L., Feng, C. C., \& Wang, Q. (2016). The Dynamic Relationship between Housing Prices and Land Prices in Beijing-An Empirical Analysis Based on Structural Equation Model. Geographical Research, 35, 1831-1845.

Gao, B., Wang, W. L., \& Li, X. (2013). Expected, the Income Gap between China's Urban Housing Prices and Rent "Scissors" Mystery. Economic Research, 48, 100-112, 126.

Kuang, D. (2010). Expectations, Speculation, and Housing Price Fluctuations in Chinese Cities. Economic Research, 45, 67-78.

Li, G. S., \& Guo, H. (2020). Research on the Prediction of Housing Prices in Nanjing Based on GM $(1,1)$ Model. Journal of Jianghan University (Natural Science Edition), $48,10-13$.

Li, Y. Y. (2014). Housing Prices and Demand-Driven Ripple Effects-On the Strategy of China's Housing Problem. Economics (Quarter Journal), 13, 443-464.

Liu, Y. Z., \& Xu, Y. (2019). An Empirical Analysis of Factors Influencing Housing Prices in the Yangtze River Delta of China-Based on a Spatial Perspective. Journal of Hainan University (Humanities and Social Sciences Edition), 37, 77-85.

Qiu, Q. R., \& Yu, T. (2011) BP Neural Network Based on Principal Component Analysis to Predict Housing Prices. Journal of Hunan University of Arts and Science (Natural Science Edition), 23, 24-26, 36.

Wang, D. H., Guan, W. J., \& Zhao, Z. B. (2015). The Impact of Land and Housing Supply on Housing Price Changes and Economic Growth-Also on the Reasons for China's High Housing Prices and Continued Rising. Financial Research, 2015, 50-67.

Yuan, D., He, Q. G., \& Zhao, B. (2016). Research on the Influencing Factors of House Price Changes: A Literature Review. Economics and Management Research, 37, 77-85.

Zhang, H., \& Li, Z. F. (2016). House Price Expectations, Land Prices and Real Estate Business Behavior. Management Review, 28, 52-61.

Zhang, J. (2014). Analysis of the Factors Influencing the Price of Commercial Housing in Suzhou and the Prediction of Housing Prices. Suzhou: Suzhou University.

Zhu, S. (2020). Rates and Per Capita Disposable Income of the Relationship between Research-Based on Empirical Analysis of Chongqing. Twice, 2020, 13, 17. 